\title{
Transmission of Grapevine Leafroll-associated Virus 3 by Vine Mealybug, Planococcus ficus (Signoret), to Grapevines Treated with Imidacloprid
}

\author{
E. Allsopp
}

ARC Infruitec-Nietvoorbij ${ }^{1}$, Private Bag X5026, 7599 Stellenbosch, South Africa

Submitted for publication: November 2014

Accepted for publication: December 2014

Key words: Grapevine leafroll virus, vine mealybug, Planococcus ficus, virus transmission

Grapevine leafroll disease is widely accepted to be the most damaging grapevine virus disease in South Africa. The current industry strategy to limit leafroll infection in new vineyards includes treating newly planted grapevines with a systemic insecticide like imidacloprid and rogueing all grapevines that exhibit leafroll symptoms. A tendency by some producers to eschew rogueing and rely solely on imidacloprid applications to control vine mealybug and so protect new vineyards from leafroll infection gave rise to this study. Two bioassays were conducted to determine if Planococcus ficus (Signoret) nymphs can transmit grapevine leafroll-associated virus $3(G L R a V-3)$ to potted indicator grapevines treated with imidacloprid applied through the soil five months before exposure to viruliferous mealybugs. Ten of 21 leafroll-free grapevines treated with imidacloprid tested positive for GLRaV-3 seven to eight weeks after being exposed to viruliferous first- and second-instar $P$. ficus nymphs. This means that the systemic applications of imidacloprid to newly planted, virus-free vineyards will not necessarily protect the vines from GLRaV-3 if they become infested by viruliferous vine mealybugs, although the insecticide provides effective mealybug control and helps to prevent the secondary spread of leafroll infection in these vineyards. To control the spread of leafroll virus to newly planted, leafroll-free vineyards, all grapevines that serve as sources of infection should be removed. Where this is not feasible, vectors should be monitored and controlled rigorously in infested and disease-free vineyards alike, while all infected grapevines should be removed from new vineyards as they begin to develop leafroll symptoms.

\section{INTRODUCTION}

Grapevine leafroll disease is widely accepted to be the most damaging grapevine virus disease in South Africa, with grapevine leafroll-associated virus $3(\mathrm{GLRaV}-3)$ the most prevalent leafroll-associated virus (Pietersen, 2006). The vine mealybug, Planococcus ficus (Signoret) (Hemiptera: Pseudococcidae), is the most common and efficient vector of GLRaV-3 in South Africa (Walton \& Pringle, 2004; Douglas \& Krüger, 2008). Currently, the industry strategy to limit leafroll infection in newly planted, leafroll-free vineyards in South Africa is based on a multi-pronged approach that includes treating young grapevines with a systemic insecticide like imidacloprid shortly after planting; monitoring for leafroll symptoms in these vineyards over two seasons, and removing all leafroll-infected grapevines, known as rogueing (Pietersen, 2006); monitoring and controlling mealybug in adjacent leafroll-infected vineyards where rogueing is not feasible; and ensuring that workers and equipment do not move from mealybug-infested vineyards to the virus-free vineyards. Concern was raised when it was noticed that, in an effort to reduce costs, some producers no longer applied mealybug control in adjacent leafroll-infected vineyards or the rogueing of symptomatic vines, but relied solely on imidacloprid applications to control mealybug in newly planted vineyards and to keep them free from infection by GLRaV-3.

Imidacloprid belongs to the class of chemicals known as neonicotinoids. It acts on the central nervous system of insects by blocking the nicotinergic neuronal pathway, which interferes with signal transmission. When applied as a systemic treatment, imidacloprid has to be ingested by the target insect before it takes effect. Within minutes to hours after ingestion, imidacloprid causes the target insects to stop feeding and death generally occurs within 24 to $48 \mathrm{~h}$, although it may take several days (Anonymous, 2012). Tsai et al. (2008) showed that first-instar grapevine mealybug

\footnotetext{
${ }^{1}$ The Fruit, Vine and Wine Institute of the Agricultural Research Council

Corresponding author: E-mail address: allsoppe@arc.agric.za

Acknowledgements: The author wishes to thank Levocia Williams and Lydia Maart of the Pest Management Division at the ARC Infruitec-Nietvoorbij for technical assistance, and Marika van der Merwe and Elize Jooste of the ARC-Plant Protection Research Institute for the PCR analyses. Funding for this research was provided by Winetech and the Agricultural Research Council.
} 
nymphs can acquire GLRaV-3 and inoculate uninfected grapevines within one hour. Douglas and Krüger (2008) demonstrated that a single nymph of $P$. ficus or Pseudococcus longispinus can infect a healthy grapevine with GLRaV-3. In a review of grapevine leafroll management, Almeida et al. (2013) cautioned that, although systemic insecticides may reduce mealybug populations very effectively, they may not necessarily protect grapevines from virus spread.

The aim of this investigation was to determine if $P$. ficus nymphs can transmit GLRaV-3 to indicator grapevines treated with imidacloprid applied as a soil drench.

\section{MATERIALS AND METHODS}

\section{Bioassay 1}

Twelve Cabernet franc grapevines at the beginning of bud burst (BBCH scale 007) and free from GLRaV-3 were obtained from Vititec (Pty) Ltd Plant Improvement Organisation (Paarl, South Africa) in September 2012. They were planted in $12 \mathrm{~L}$ (30 cm diameter) plastic pots containing a sand/ bark potting medium mixture. Three weeks after budding, when the first leaves began to unfold, $1.5 \mathrm{~mL}$ of imidacloprid (Confidor ${ }^{\circledR} 350$ SC, supplied by Bayer CropScience) in $250 \mathrm{~mL}$ of water was applied to each of 10 grapevines as a soil drench according to the registration holder's instructions. Two plants were kept as untreated controls, the number being limited by the availability of indicator plants. Plants were allowed to grow in an insect-proof enclosure at the Vititec nursery until February 2013. The exposure of the indicator plants to viruliferous $P$. ficus nymphs took place in February because the virus concentration in the virus source vines would be sufficient to optimise virus acquisition by the mealybug nymphs. It also was considered to be a reasonable reflection of the real-life situation, since $P$. ficus populations in vineyards and the virus concentration in leafroll-infected grapevines begin to peak at this time of the season, thereby creating favourable conditions for virus transmission.

Egg sacks from a $P$. ficus culture maintained on butternut squash at the ARC Infruitec-Nietvoorbij were placed on the leaves of Cabernet Sauvignon shoots collected from two grapevines on the Nietvoorbij research farm. Both grapevines tested positive for the presence of GLRaV-3 with an enzymelinked immunosorbent assay (ELISA) performed by Vititec prior to the commencement of the bioassay. Hatched nymphs were allowed to feed on these leaves for $48 \mathrm{~h}$, after which they were transferred to the Cabernet franc indicator vines treated with imidacloprid and the two untreated vines. Small leaf sections containing nymphs were used to transfer the nymphs without disturbance or injury. As the leaf sections desiccated, the nymphs moved freely onto the Cabernet franc leaves. Groups of five nymphs were placed on six marked leaves of each of the experimental vines (30 nymphs per plant). The treated and control plants were maintained in separate insect-rearing rooms with natural light at $25^{\circ} \mathrm{C}$ and $60 \%$ relative humidity.

After $72 \mathrm{~h}$ the plants were sprayed with malathion to kill all the mealybugs still alive. Plants were kept in a glasshouse for seven weeks to allow sufficient time for virus multiplication. After seven weeks (at the onset of senescence, $\mathrm{BBCH}$ scale 991), the petioles of the leaves on which mealybug nymphs were placed were collected and sent to the Virology Unit of the ARC-Plant Protection Research Institute (PPRI) at Roodeplaat near Pretoria. Nested reverse transcriptase polymerase chain reaction (RT-PCR) was performed according to the method of Ling et al. (2001) to determine if GLRaV-3 was present in the samples. The remaining leaves of the experimental vines were sent to an independent laboratory (Hearshaw \& Kinnes) to determine the concentration of imidacloprid in the leaves.

\section{Bioassay 2}

Thirty Cabernet franc grapevines at the beginning of bud burst (BBCH-scale 007) and free from GLRaV-3 were obtained from Vititec in September 2013 and planted in $12 \mathrm{~L}$ (30 $\mathrm{cm}$ diameter) plastic pots containing a sand/bark potting medium mixture. Three weeks after budding, when the first leaves began to unfold, $0.75 \mathrm{~g}$ of imidacloprid (Confidor ${ }^{\circledR}$ $70 \mathrm{WG}$, supplied by Bayer CropScience) in $250 \mathrm{~mL}$ of water was applied to each of 20 grapevines as a soil drench according to the registration holder's instructions. Ten Cabernet franc indicator vines, not treated with imidacloprid, were kept aside as untreated controls. Plants were allowed to grow in an insect-proof enclosure at the Vititec nursery until February 2014.

In February 2014, petiole samples of the 20 imidacloprid treated and 10 untreated vines were sent to the ARC-PPRI Virology Unit to be tested for the presence of GLRaV-3. Samples were tested using ELISA, and those with borderline results were re-tested using nested RT-PCR. All plants tested negative for GLRaV-3.

Egg sacks from the $P$. ficus culture maintained on butternut squash at the ARC Infruitec-Nietvoorbij were placed on the leaves of vine shoots collected from the same leafroll-infected grapevines at the Nietvoorbij research farm used in Bioassay 1. Hatched nymphs were allowed to feed on these leaves for $48 \mathrm{~h}$, after which they were transferred to the 20 indicator plants treated with imidacloprid, using the same leaf section method as in Bioassay 1. Groups of five nymphs were placed on six leaves of each of the 20 treated vines (30 nymphs per plant). The 10 untreated control plants were not exposed to mealybugs. Treated and untreated plants were maintained in separate insect-rearing rooms with natural light at $25^{\circ} \mathrm{C}$ and $60 \%$ relative humidity.

After $72 \mathrm{~h}$ the treated plants were sprayed with malathion to kill any remaining mealybugs. Plants were kept in a glasshouse for eight weeks to allow sufficient time for virus multiplication. After eight weeks (at the onset of senescence, BBCH scale 991), the petioles of the leaves on which P. ficus nymphs were placed and petioles from the 10 untreated control vines (five petioles per plant) were collected and sent to the ARC-PPRI Virology Unit. Nested RT-PCR was performed to determine if GLRaV-3 was present in the samples.

\section{RESULTS AND DISCUSSION}

\section{Bioassay 1}

Visual observation revealed that some $P$. ficus nymphs were still alive after $72 \mathrm{~h}$, although no longer moving or feeding actively. Chemical analysis by an independent laboratory confirmed that $5 \mathrm{ppm}$ imidacloprid was present in the leaves of the treated grapevines at the end of the bioassay. According 
to information supplied by Bayer CropScience, this is well above the lethal concentration of $0.7 \mathrm{ppm}$ determined for citrus mealybug (Ralf Nauen, personal communication, 2012). The results from the nested RT-PCR showed that seven of the 10 grapevines treated with imidacloprid and one of the two untreated vines tested positive for GLRaV-3.

\section{Bioassay 2}

Eight weeks after exposure to $P$. ficus nymphs, when the final petiole samples were taken, the leaves on which mealybugs were released of four of the imidacloprid-treated plants had already senesced to such an extent that the petioles were no longer suitable for virus testing. Five more samples were lost in transit to the ARC-PPRI Virology Unit. Petiole samples from three of the eleven remaining imidaclopridtreated plants tested positive for GLRaV-3, while all of the untreated control plants tested negative. This confirms that virus transmission by P. ficus nymphs was responsible for the treated plants testing positive for GLRaV-3.

The results of the two bioassays show that first- and second-instar nymphs of $P$. ficus are able to transmit GLRaV-3 to grapevines before the imidacloprid applied five months earlier took sufficient effect to stop them feeding. Similar results have been found with other sucking insects. Rubinstein et al. (1999) showed that viruliferous whiteflies, Bemisia tabaci (Gennadius), were able to inoculate imidacloprid-treated tomato plants with tomato yellow leaf curl virus (Family: Geminiviridae) before they died. Jacobson and Kennedy (2013) found no reduction in the transmission of tomato spotted wilt virus (Family: Bunyaviridae) by western flower thrips (Frankliniella occidentalis Pergande) to banana pepper (Capsicum annuum) plants treated with imidacloprid.

The possibility that the presence of imidacloprid in a grapevine and variation in its concentration in a vine during the season may affect virus transmission efficacy and transmission rate by $P$. ficus nymphs falls beyond the scope of this study, but warrants further investigation.

The result of this investigation has important implications for leafroll management because it has demonstrated that soil applications of imidacloprid to newly planted grapevines will not prevent the spread of grapevine leafroll disease to these vines if leafroll-infected grapevines remain in adjacent vineyards and vectors are not adequately controlled there. This underscores the importance of rogueing infected grapevines that act as sources of infestation and controlling insect vectors, as advocated by Almeida et al. (2013) and Pietersen et al. (2013), for an integrated approach to control the spread of leafroll disease. Ideally, all leafroll-infected grapevines in existing vineyards that serve as virus sources should be removed if new vineyards are to be kept virus free. Where this is not possible, rigorous monitoring and control of vine mealybug and other vectors in infected vineyards, as well as in newly planted vineyards, should be combined with the rogueing of all grapevines that begin to show leafroll symptoms in newly planted vineyards. Imidacloprid should be applied to newly planted vines as a soil drench to prevent the secondary spread of leafroll in these vineyards.

Imidacloprid's long persistence in plants and the fact that it binds virtually irreversibly to the postsynaptic nicotinic acetyl-choline receptors in an insect's central nervous system mean that, even when the concentration of imidacloprid in a plant falls below the lethal concentration, prolonged feeding results in the accumulation of a lethal dose that eventually kills the insect (Tennekes, 2010; Anonymous, 2012). This explains why imidacloprid provides effective mealybug control over a long period when applied to the soil. Because of this long residual action, and to save on costs for mealybug control, some producers were found to rely only on systemic applications of imidacloprid every year or even every second year. However, prolonged exposure to sub-lethal doses of imidacloprid in host plants increases the risk of resistance to the insecticide developing. For this reason it is imperative to alternate imidacloprid with insecticides that have a different mode of action in an anti-resistance strategy.

\section{CONCLUSIONS}

This investigation has shown that grapevine mealybug nymphs can transmit GLRaV-3 to potted grapevines treated with imidacloprid applied as a soil drench shortly after bud burst, i.e. five months prior to exposure to viruliferous mealybugs. Systemic applications of imidacloprid to newly planted, virus-free vineyards therefore will not necessarily protect the vines from transmission of GLRaV-3 if they become infested by viruliferous $P$. ficus from adjacent vineyards. Imidacloprid does, however, provide effective mealybug control and remains a useful tool to prevent the secondary spread of leafroll disease within newly planted vineyards.

To control the spread of leafroll virus to newly planted, leafroll-free vineyards, all leafroll-infected grapevines in surrounding vineyards that serve as virus sources should be removed. Where this is not feasible, vectors should be monitored and controlled rigorously in both the infected and disease-free vineyards, while all infected grapevines should be removed from new vineyards as they begin to develop leafroll symptoms. Producers should alternate imidacloprid with insecticides that have different modes of action as part of an anti-resistance strategy to prevent mealybugs from developing resistance to the product.

\section{LITERATURE CITED}

Almeida, R.P.P., Daane, K.M., Bell, V.A., Blaisdell, G.K., Cooper, M.L., Herrbach, E. \& Pietersen, G., 2013. Ecology and management of grapevine leafroll disease. Frontiers in Microbiol. 4, 1-13.

Anonymous, 2012. Imidacloprid - Expert Overview - Bayer. Available at http://www.apiservices.com/ articles/us/imidacloprid_bayer.htm (26 February 2013).

Douglas, N. \& Krüger, K., 2008. Transmission efficiency of grapevine leafroll-associated virus 3 (GLRaV-3) by the mealybugs Planococcus ficus and Pseudococcus longispinus (Hemiptera: Pseudococcidae). Eur. J. Plant Pathol. 122, 201-212.

Jacobson, A.L. \& Kennedy, G.C., 2013. Effect of cyantraniliprole on feeding behaviour and virus transmission of Frankliniella fusca and Frankliniella occidentalis (Thysanoptera: Thripidae) on Capsicum annuum. Crop Prot. 54, 251-258.

Ling K.-S., Zhu, H.-Y., Petrovic, N. \& Gonsalves, D., 2001. Comparative effectiveness of ELISA and RT-PCR for detecting grapevine leafrollassociated closterovirus-3 in field samples. Am. J. Enol. Vitic. 52, 21-27. 
Pietersen, G., 2006. Spatio-temporal distribution dynamics of grapevine leafroll disease in Western Cape vineyards. Extended abstracts of the $15^{\text {th }}$ Meeting of the International Council for the Study of Virus and Virus-like Diseases of the Grapevine, April 2006, Stellenbosch, South Africa. pp. 126 $-127$.

Pietersen, G., Spreeth, N., Oosthuizen, T., Van Rensburg, A., Van Rensburg, M., Lottering, D., Rossouw, N. \& Tooth, D., 2013. Control of grapevine leafroll disease spread at a commercial wine estate in South Africa: A case study. Am. J. Enol. Vitic. 64, 296-306.

Rubinstein, G., Morin, S. \& Czosnek, H., 1999. Transmission of tomato yellow leaf curl geminivirus to imidacloprid treated tomato plants by the whitefly Bemisia tabaci (Homoptera: Aleyrodidae). J. Econ. Entomol. 92, 658-662.
Tennekes, H.A., 2010. The significance of the Druckrey-Küpfmüller equation for risk assessment - The toxicity of neonicotinoid insecticides to arthropods is reinforced by exposure time. Toxicol. 276, 1-4.

Tsai, C.-W., Chau, J., Fernandez, L., Bosco, D., Daane, K.M. \& Almeida, R.P.P., 2008. Transmission of grapevine leafroll-associated virus 3 by the vine mealybug (Planococcus ficus). Phytopathol. 98, 1093-1098.

Walton, V.M. \& Pringle, K.L., 2004. Vine mealybug, Planococcus ficus (Signoret) (Hemiptera: Pseudococcidae), a key pest in South African vineyards. A review. S. Afr. J. Enol. Vitic. 25, 54-62. 